\title{
ANALISIS KESTABILAN MODEL PENYEBARAN PENYAKIT KAKI GAJAH (FILARIASIS) \\ (Data Kasus Kronis Filariasis di Kabupaten Sambas)
}

\author{
Nurhajijah, Helmi, Woro Budiartini Partiwi
}

\begin{abstract}
INTISARI
Filariasis merupakan penyakit menular yang disebabkan oleh infeksi cacing Filaria yang ditularkan melalui gigitan nyamuk. Penyakit ini tersebar luas di pedesaan dan perkotaan yang beriklim tropis serta dapat menyerang seтиa golongan tanpa mengenal usia dan jenis kelamin. Model matematika dalam penelitian ini mendeskripsikan tentang penyebaran penyakit Filariasis berdasarkan asumsi dan nilai parameter yang digunakan. Penelitian ini menggunakan model matematika yang terdiri dari empat subpopulasi pada populasi manusia yaitu manusia yang rentan terhadap penyakit $\left(S_{h}\right)$, manusia yang terjangkit penyakit $\left(E_{h}\right)$, manusia yang terinfeksi penyakit $\left(I_{h}\right)$, dan manusia yang kebal terhadap penyakit $\left(R_{h}\right)$ serta tiga subpopulasi pada populasi nyamuk yaitu nyamuk yang rentan terhadap penyakit $\left(S_{v}\right)$, nyamuk yang terjangkit penyakit $\left(E_{v}\right)$, dan nyamuk yang terinfeksi penyakit $\left(I_{v}\right)$. Model matematika yang telah dibentuk selanjutnya dianalisis untuk mengetahui perilaku dari sistem dengan menggunakan simulasi numerik. Simulasi model matematika dan nilai parameter menunjukkan bahwa terdapat dua titik kesetimbangan yaitu titik kesetimbangan bebas penyakit yang bersifat stabil asimtotik dan titik kesetimbangan endemik penyakit yang bersifat tidak stabil. Analisis sensitivitas dari sistem dalam penelitian ini menunjukkan bahwa semakin besar keberhasilan pemberian obat pencegahan Filariasis pada manusia menyebabkan nilai bilangan reproduksi dasar kurang dari satu dan semakin kecil keberhasilan pemberian obat pencegahan Filariasis pada manusia menyebabkan nilai bilangan reproduksi dasar lebih dari satu.
\end{abstract}

Kata kunci : model matematika, Filariasis, bilangan reproduksi dasar

\section{PENDAHULUAN}

Model matematika merupakan salah satu bentuk penerapan ilmu matematika yang dapat digunakan untuk menginterpretasikan masalah pada dunia nyata ke dalam bentuk persamaan maupun pertidaksamaan matematika. Model matematika merupakan salah satu metode yang dapat digunakan untuk dinamika penyebaran penyakit epidemik salah satunya adalah penyakit Filariasis. Filariasis atau penyakit kaki gajah merupakan salah merupakan penyakit menular yang disebabkan oleh cacing Filaria dan dapat ditularkan melalui gigitan nyamuk. Penyakit ini tersebar luas di perdesaan dan perkotaan yang beriklim tropis serta dapat menyerang semua golongan tanpa mengenal usia dan jenis kelamin [1]. Penyakit ini bersifat kronis dan bila tidak segera mendapatkan penanganan maka menimbulkan cacat menetap berupa pembesaran kaki, lengan, dan alat kelamin. Berdasarkan data yang diberikan oleh Dinas Kesehatan Provinsi, pada tahun 2017 Kalimantan Barat tercatat memiliki 255 kasus kronis Filariasis yang terdiri dari sembilan kabupaten endemis dengan mikrofilaria rate $>1 \%$. Pada tahun 2017 , Kabupaten Sambas tercatat memiliki kasus kronis terbesar dibanding dengan 8 kabupaten lainnya yaitu sebanyak 62 kasus kronis dengan jumlah penduduk 526.367 jiwa.

Tujuan dari penelitian ini adalah (1) mengetahui model penyebaran penyakit Filariasis, (2) menganalisis kestabilan model penyebaran penyakit Filariasis di sekitar titik kesetimbangan, (3) mengetahui pengaruh pemberian obat pencegahan Filariasis pada subpopulasi manusia yang rentan terhadap penyebaran penyakit Filariasis pada level set $R_{0}$. Penelitian ini membahas tentang model penyebaran penyakit Filariasis dalam bentuk sistem persamaan diferensial nonlinear yang bersifat tertutup pada suatu wilayah tertentu dan mengabaikan usia pada masing-masing populasi dengan melakukan pemberian obat pencegahan Filariasis pada subpopulasi manusia yang rentan. Individu yang berhasil dengan obat pencegahan Filariasis yang diberikan tidak dapat tertular penyakit kembali. 
Analisis kestabilan model penyebaran penyakit Filariasis dimulai dengan membuat asumsi-asumsi dan mendefinisikan parameter yang digunakan pada model yang kemudian dibentuk ke dalam diagram transfer model matematika penyebaran penyakit Filariasis. Berdasarkan diagram transfer tersebut dibentuk model matematika penyebaran penyakit Filariasis. Kemudian, menentukan titik kesetimbangan dari model. Model yang diperoleh dalam penelitian ini adalah model dengan bentuk sistem persamaan diferensial nonlinear yang memiliki dua titik kesetimbangan yaitu titik kesetimbangan bebas penyakit dan titik kesetimbangan endemik. Langkah selanjutnya, melakukan linearisasi model dengan membentuk matriks Jacobian dari sistem persamaan [2]. Berdasarkan hasil dari matriks Jacobian, diperoleh nilai-nilai eigen. Selanjutnya, menentukan Matriks Generasi Mendatang (NGM) dari sistem persamaan. NGM diperoleh dari model persamaan subpopulasi yang terjangkit dan terinfeksi pada populasi manusia maupun nyamuk. Berdasarkan matriks NGM diperoleh bilangan reproduksi dasar $\left(R_{0}\right)$ yang merupakan suatu bilangan yang menyatakan rata-rata individu baru yang dapat terinfeksi karena adanya satu individu yang terinfeksi yang terjadi dalam subpopulasi rentan [3]. Langkah terakhir adalah melakukan analisis numerik. Analisis yang dilakukan adalah analisis kestabilan sistem yang dilakukan dengan mensubstitusikan data numerik ke dalam nilai eigen yang telah diperoleh sebelumnya pada masing-masing titik kesetimbangan yang kemudian dianalisis berdasarkan dari sifat stabilitas sistem [4], serta analisis penyebaran penyakit Filariasis pada level set $R_{0}$ yang dilakukan menggunakan analisis sensitivitas dengan menggunakan grafik simulasi data kasus kronis Filariasis di Kabupaten Sambas, Kalimantan Barat.

\section{MODEL MATEMATIKA PENYEBARAN PENYAKIT FILARIASIS}

Model matematika penyebaran penyakit Filariasis merupakan suatu model matematika yang menggambarkan dinamika penyebaran penyakit Filariasis antara populasi manusia dan populasi nyamuk. Model matematika dalam penelitian ini merupakan model penyebaran penyakit host-vektor yang terdiri dari dua populasi yaitu populasi manusia yang berperan sebagai host dan populasi nyamuk yang berperan sebagai vektor. Berikut merupakan asumsi yang digunakan untuk membentuk model penyebaran penyakit Filariasis yaitu:

1. Penyebaran penyakit Filariasis pada populasi manusia dibagi empat subpopulasi yaitu subpopulasi manusia yang rentan terhadap penyakit, manusia yang terjangkit, manusia yang terinfeksi, dan manusia yang kebal terhadap penyakit, sedangkan populasi nyamuk terbagi menjadi tiga subpopulasi yaitu subpopulasi nyamuk yang rentan terhadap penyakit, nyamuk yang terjangkit, dan nyamuk yang terinfeksi.

2. Laju kelahiran pada manusia dan nyamuk dianggap konstan.

3. Dalam populasi manusia diasumsikan terdapat sejumlah orang yang sudah terinfeksi penyakit Filariasis.

4. Penularan penyakit Filariasis terjadi karena adanya kontak langsung antara nyamuk dan manusia yang terinfeksi Filariasis.

5. Jumlah populasi manusia dan nyamuk dianggap konstan sedangkan penularan penyakit Filariasis berlangsung secara terus-menerus.

6. Manusia yang telah terinfeksi penyakit Filariasis tidak dapat sembuh dari penyakit.

7. Individu yang terinfeksi pada subpopulasi manusia yang terinfeksi dieliminasi dari subpopulasi.

8. Manusia yang rentan terkena penyakit dapat langsung berpindah ke subpopulasi manusia yang kebal terhadap penyakit apabila pemberian obat pencegahan Filariasis yang dilakukan berhasil dan langsung berpindah ke subpopulasi manusia yang terjangkit apabila pemberian obat pencegahan Filariasis yang dilakukan tidak berhasil.

9. Laju kematian manusia dan nyamuk pada setiap populasi dianggap konstan.

10. Pengaruh migrasi diabaikan sehingga penyebaran penyakit bersifat tertutup dalam suatu populasi. Berdasarkan asumsi-asumsi tersebut, diperoleh model dinamika penyebaran penyakit Filariasis 
pada manusia dan nyamuk seperti pada Gambar 1 berikut

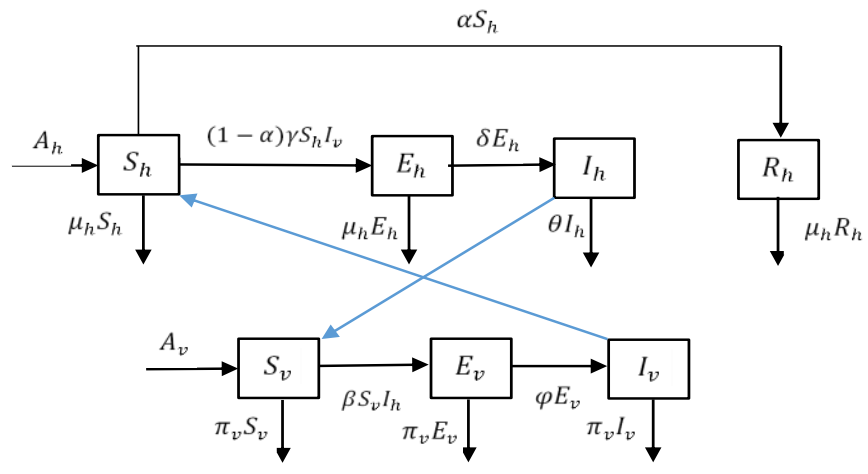

Gambar 1. Diagram Dinamika Penyebaran Penyakit Filariasis pada Manusia dan Nyamuk

Berdasarkan Gambar 1, diperoleh model penyebaran penyakit Filariasis sebagai berikut:

$$
\begin{aligned}
\frac{d S_{h}}{d t} & =A_{h}-(1-\alpha) \gamma S_{h} I_{v}-\left(\mu_{h}+\alpha\right) S_{h} \\
\frac{d E_{h}}{d t} & =(1-\alpha) \gamma S_{h} I_{v}-\left(\mu_{h}+\delta\right) E_{h} \\
\frac{d I_{h}}{d t} & =\delta E_{h}-\theta I_{h} \\
\frac{d R_{h}}{d t} & =\alpha S_{h}-\mu_{h} R_{h} \\
\frac{d S_{v}}{d t} & =A_{v}-\beta I_{h} S_{v}-\pi_{v} S_{v} \\
\frac{d E_{v}}{d t} & =\beta S_{v} I_{h}-\left(\pi_{v}+\varphi\right) E_{v} \\
\frac{d I_{v}}{d t} & =\varphi E_{v}-\pi_{v} I_{v}
\end{aligned}
$$

dengan $A_{h}, \mu_{h}, \gamma, \delta, \theta, A_{v}, \pi_{v}, \beta, \varphi>0, S_{h}, E_{h}, I_{h}, R_{h}, S_{v}, E_{v}, I_{v} \geq 0$ dan $0<\alpha<1$, serta keterangan sebagai berikut:

$A_{h}$ : laju kelahiran alami pada populasi manusia (host)

$\mu_{h}$ : laju kematian alami pada populasi manusia (host)

$\gamma$ : laju penyebaran penyakit dari populasi nyamuk ke populasi manusia

$\theta \quad$ : laju eliminasi manusia yang terinfeksi penyakit Filariasis

$\alpha$ : presentase keberhasilan pemberian obat pencegahan Filariasis pada populasi manusia

$\delta$ : laju perpindahan subpopulasi manusia yang terjangkit ke subpopulasi manusia yang terinfeksi

$A_{v}$ : laju kelahiran alami pada populasi nyamuk (vektor)

$\pi_{v}$ : laju kematian alami pada populasi nyamuk (vektor)

$\beta$ : laju kontak penularan penyakit dari populasi manusia ke populasi nyamuk

$\varphi$ : laju perpindahan subpopulasi nyamuk yang terjangkit ke subpopulasi nyamuk yang terinfeksi

Selanjutnya adalah menentukan titik kesetimbangan dari Sistem Persamaan (1). Berdasarkan Sistem Persamaan (1) diperoleh dua titik kesetimbangan yaitu titik kesetimbangan bebas penyakit $\left(T K_{1}\right)$ dan titik kesetimbangan endemik penyakit $\left(T K_{2}\right)$ sebagai berikut:

$$
\begin{gathered}
T K_{1}=\left(S_{h 1}=\frac{A_{h}}{\mu_{h}+\alpha}, E_{h 1}=0, I_{h 1}=0, R_{h 1}=\frac{\alpha A_{h}}{\left(\mu_{h}+\alpha\right) \mu_{h}}, S_{v 1}=\frac{A_{v}}{\pi_{v}}, E_{v 1}=0, I_{v 1}=0\right) \\
T K_{2}=\left(S_{h 2}=\frac{\left(\theta\left(\mu_{h}+\delta\right) \pi_{v}+A_{h} \beta \delta\right) \pi_{v}\left(\varphi+\pi_{v}\right)}{\beta \delta\left(\left(\mu_{h}+\alpha\right) \pi_{v}{ }^{2}+\varphi\left(\mu_{h}+\alpha\right) \pi_{v}-\varphi A_{v} \gamma(\alpha-1)\right)^{\prime}},\right. \\
E_{h 2}=\frac{-\theta\left(\mu_{h}+\delta\right)\left(\mu_{h}+\alpha\right) \pi_{v}{ }^{3}-\varphi \theta\left(\mu_{h}+\delta\right)\left(\mu_{h}+\alpha\right) \pi_{v}{ }^{2}-A_{h} \varphi A_{v} \beta \delta \gamma(\alpha-1)}{\beta \delta\left(\mu_{h}+\delta\right)\left(\left(\mu_{h}+\alpha\right) \pi_{v}^{2}+\varphi\left(\mu_{h}+\alpha\right) \pi_{v}-\varphi A_{v} \gamma(\alpha-1)\right)}, \\
I_{h 2}=\frac{-\theta\left(\mu_{h}+\delta\right)\left(\mu_{h}+\alpha\right) \pi_{v}{ }^{3}-\varphi \theta\left(\mu_{h}+\delta\right)\left(\mu_{h}+\alpha\right) \pi_{v}{ }^{2}-\varphi A_{v} \beta \delta \gamma(\alpha-1)}{\beta \theta\left(\mu_{h}+\delta\right)\left(\left(\mu_{h}+\alpha\right) \pi_{v}{ }^{2}+\varphi\left(\mu_{h}+\alpha\right) \pi_{v}-\varphi A_{v} \gamma(\alpha-1)\right)}, \\
R_{h 2}=\frac{\alpha \pi_{v}\left(\theta\left(\mu_{h}+\delta\right) \pi_{v}+A_{h} \beta \delta\right)\left(\varphi+\pi_{v}\right)}{\beta \delta\left(\left(\mu_{h}+\alpha\right) \pi_{v}{ }^{2}+\varphi\left(\mu_{h}+\alpha\right) \pi_{v}-\varphi A_{v} \gamma(\alpha-1)\right) \mu_{h}},
\end{gathered}
$$




$$
\begin{aligned}
S_{v 2} & =-\frac{\theta\left(\mu_{h}+\delta\right)\left(\left(\mu_{h}+\alpha\right) \pi_{v}{ }^{2}+\varphi\left(\mu_{h}+\alpha\right) \pi_{v}-\varphi A_{v} \gamma(\alpha-1)\right)}{(\alpha-1)\left(\theta\left(\mu_{h}+\delta\right) \pi_{v}+A_{h} \beta \delta\right) \varphi \gamma} \\
E_{v 2} & =\frac{\theta\left(\mu_{h}+\delta\right)\left(\mu_{h}+\alpha\right) \pi_{v}{ }^{3}+\varphi \theta\left(\mu_{h}+\delta\right)\left(\mu_{h}+\alpha\right) \pi_{v}{ }^{2}+A_{h} \varphi A_{v} \beta \delta \gamma(\alpha-1)}{(\alpha-1)\left(\theta\left(\mu_{h}+\delta\right) \pi_{v}+A_{h} \beta \delta\right) \varphi \gamma\left(\varphi+\pi_{v}\right)}, \\
I_{v 2} & \left.=\frac{\theta\left(\mu_{h}+\delta\right)\left(\mu_{h}+\alpha\right) \pi_{v}{ }^{3}+\varphi \theta\left(\mu_{h}+\delta\right)\left(\mu_{h}+\alpha\right) \pi_{v}{ }^{2}+A_{h} \varphi A_{v} \beta \delta \gamma(\alpha-1)}{(\alpha-1)\left(\theta\left(\mu_{h}+\delta\right) \pi_{v}+A_{h} \beta \delta\right) \pi_{v} \gamma\left(\varphi+\pi_{v}\right)}\right)
\end{aligned}
$$

Titik kesetimbangan $T K_{1}$ menunjukkan kondisi bebas penyakit Filariasis pada suatu daerah dengan adanya pemberian obat pencegahan Filariasis pada subpopulasi manusia yang rentan terhadap penyakit $\left(S_{h}\right)$. Pada kondisi ini tidak ada individu yang terjangkit dan terinfeksi penyakit Filariasis baik pada populasi manusia maupun nyamuk. Titik Kesetimbangan $T K_{2}$ menunjukkan kondisi masih adanya penyakit Filariasis dalam suatu populasi pada suatu daerah karena ketidakberhasilan dari obat pencegahan Filariasis yang diberikan pada subpopulasi manusia yang rentan terhadap penyakit $\left(S_{h}\right)$. Pada kondisi ini masih adanya individu yang terjangkit dan terinfeksi penyakit Filariasis baik pada populasi manusia maupun nyamuk.

\section{ANALISIS KESTABILAN MODEL PENYEBARAN PENYAKIT FILARIASIS}

Analisis kestabilan sistem persamaan diferensial nonlinear dilakukan melalui linearisasi terlebih dahulu. Linearisasi dicari menggunakan matriks Jacobian dari Sistem Persamaan (1) sehingga diperoleh matriks J sebagai berikut:

$$
\mathbf{J}=\left(\begin{array}{ccccccc}
-(1-\alpha) \gamma I_{v}-\mu_{h}-\alpha & 0 & 0 & 0 & 0 & 0 & -(1-\alpha) \gamma S_{h} \\
(1-\alpha) \gamma I_{v} & -\mu_{h}-\delta & 0 & 0 & 0 & 0 & (1-\alpha) \gamma S_{h} \\
0 & \delta & -\theta & 0 & 0 & 0 & 0 \\
\alpha & 0 & 0 & -\mu_{h} & 0 & 0 & 0 \\
0 & 0 & -\beta S_{v} & 0 & -\beta I_{h}-\pi_{v} & 0 & 0 \\
0 & 0 & \beta S_{v} & 0 & \beta I_{h} & -\pi_{v}-\varphi & 0 \\
0 & 0 & 0 & 0 & 0 & \varphi & -\pi_{v}
\end{array}\right)
$$

Selanjutnya dengan mensubstitusikan Persamaan (2) ke dalam Persamaan (4) diperoleh matriks $\mathbf{J}_{\mathbf{1}}$ sebagai berikut

$$
\mathbf{J}_{\mathbf{1}}=\left(\begin{array}{ccccccc}
-\mu_{h}-\alpha & 0 & 0 & 0 & 0 & 0 & -\frac{(1-\alpha) \gamma A_{h}}{\mu_{h}+\alpha} \\
0 & -\mu_{h}-\delta & 0 & 0 & 0 & 0 & \frac{(1-\alpha) \gamma A_{h}}{\mu_{h}+\alpha} \\
0 & \delta & -\theta & 0 & 0 & 0 & 0 \\
\alpha & 0 & 0 & -\mu_{h} & 0 & 0 & 0 \\
0 & 0 & -\frac{\beta A_{v}}{\pi_{v}} & 0 & -\pi_{v} & 0 & 0 \\
0 & 0 & \frac{\beta A_{v}}{\pi_{v}} & 0 & 0 & -\pi_{v}-\varphi & 0 \\
0 & 0 & 0 & 0 & 0 & \varphi & -\pi_{v}
\end{array}\right)
$$

Kestabilan dari suatu sistem dapat diketahui dengan menentukan nilai eigen dari sistem tersebut terlebih dahulu. Nilai eigen dari matriks Jacobian $\mathbf{J}_{\mathbf{1}}$ dapat diperoleh menggunakan persamaan $\left|\mathbf{J}_{\mathbf{1}}-\lambda \mathbf{I}\right|=0$ [5]. Matriks $\mathbf{J}_{\mathbf{1}}$ merupakan matriks Jacobian hasil linearisasi untuk titik kesetimbangan bebas penyakit dan I merupakan matriks identitas, sehingga diperoleh nilai eigen untuk titik kesetimbangan bebas penyakit. Selanjutnya dengan mensubstitusikan Persamaan (3) ke dalam Persamaan (4) diperoleh matriks $\mathbf{J}_{2}$ sebagai berikut

$$
\mathbf{J}_{2}=\left(\begin{array}{ccccccc}
-m_{1}-\mu_{h}-\alpha & 0 & 0 & 0 & 0 & 0 & -(1-\alpha) \gamma m_{2} \\
m_{1} & -\mu_{h}-\delta & 0 & 0 & 0 & 0 & (1-\alpha) \gamma m_{2} \\
0 & \delta & -\theta & 0 & 0 & 0 & 0 \\
\alpha & 0 & 0 & -\mu_{h} & 0 & 0 & 0 \\
0 & 0 & \beta m_{3} & 0 & -m_{4}-\pi_{v} & 0 & 0 \\
0 & 0 & -\beta m_{3} & 0 & m_{4} & -\pi_{v}-\varphi & 0 \\
0 & 0 & 0 & 0 & 0 & \varphi & -\pi_{v}
\end{array}\right)
$$


Dengan cara yang sama juga dilakukan untuk titik kesetimbangan endemik penyakit menggunakan persamaan $\left|\mathbf{J}_{2}-\lambda \mathbf{I}\right|=0$ [5]. Matriks $\mathbf{J}_{2}$ merupakan matriks Jacobian hasil linearisasi untuk titik kesetimbangan endemik penyakit, sehingga diperoleh nilai eigen untuk titik kesetimbangan endemik penyakit.

Selanjutnya, menentukan nilai dari bilangan reproduksi dasar $\left(R_{0}\right)$. Bilangan $R_{0}$ memiliki tiga kriteria yaitu jika $R_{0}>1$ maka akan terjadi endemik yang ditandai dengan meningkatnya subpopulasi manusia yang terinfeksi. Jika $R_{0}<1$ maka tidak terjadi endemik yang ditandai dengan menurunnya subpopulasi manusia yang terinfeksi. Jika $R_{0}=1$ maka individu yang terinfeksi akan menularkan tepat kepada satu individu rentan, sehingga penyakit dalam populasi akan stabil atau menetap. Nilai $R_{0}$ merupakan nilai eigen maksimum yang diperoleh dari Matriks Generasi Mendatang (NGM). NGM dapat diperoleh dari model persamaan subpopulasi yang terjangkit dan terinfeksi pada populasi manusia maupun nyamuk [3].

Matriks NGM dari Sistem Persamaan (1) untuk titik kesetimbangan bebas penyakit diberikan oleh

$$
\mathbf{N G M}_{1}=\left[\begin{array}{cccc}
0 & 0 & 0 & \frac{(1-\alpha) \gamma A_{h}}{\pi_{v}\left(\mu_{h}+\alpha\right)} \\
\frac{\delta}{\mu_{h}+\delta} & 0 & 0 & 0 \\
0 & \frac{\beta A_{v}}{\pi_{v} \theta} & 0 & 0 \\
0 & 0 & \frac{\varphi}{\pi_{v}+\varphi} & 0
\end{array}\right]
$$

Berdasarkan matriks $\mathbf{N G M}_{\mathbf{1}}$, polinom karakteristik yang dihasilkan untuk menentukan nilai $R_{0}$ pada titik kesetimbangan bebas penyakit adalah

$$
P_{1}(x)=\lambda^{4}-\frac{A_{h} A_{v} \beta \delta \gamma \varphi(1-\alpha)}{\left(\mu_{h}+\delta\right) \pi_{v}^{2} \theta\left(\mu_{h}+\alpha\right)\left(\pi_{v}+\varphi\right)}
$$

Sehingga diperoleh nilai $R_{0}$ untuk titik kesetimbangan bebas penyakit sebagai berikut

$$
R_{0}(D F E)=\sqrt[4]{\frac{A_{h} A_{v} \beta \delta \gamma \varphi(1-\alpha)}{\left(\mu_{h}+\delta\right) \pi_{v}^{2} \theta\left(\mu_{h}+\alpha\right)\left(\pi_{v}+\varphi\right)}}
$$

Selanjutnya matriks NGM dari Sistem Persamaan (1) untuk titik kesetimbangan endemik penyakit diberikan oleh

$$
\mathbf{N G M}_{2}=\left[\begin{array}{cccc}
0 & 0 & 0 & \frac{(1-\alpha) \gamma\left(\theta\left(\mu_{h}+\delta\right) \pi_{v}+A_{h} \beta \delta\right)\left(\varphi+\pi_{v}\right)}{\beta \delta\left(\left(\mu_{h}+\alpha\right) \pi_{v}{ }^{2}+\varphi\left(\mu_{h}+\alpha\right) \pi_{v}-\varphi A_{v} \gamma(1-\alpha)\right)} \\
\frac{\delta}{\mu_{h}+\delta} & 0 & 0 & 0 \\
0 & \frac{\beta\left(\mu_{h}+\delta\right)\left(\left(-\mu_{h}-\alpha\right) \pi_{v}{ }^{2}-\varphi\left(\mu_{h}+\alpha\right) \pi_{v}+\varphi A_{v} \gamma(\alpha-1)\right)}{(\alpha-1)\left(\theta\left(\mu_{h}+\delta\right) \pi_{v}+A_{h} \beta \delta\right) \varphi \gamma} & 0 & 0 \\
0 & 0 & \frac{\varphi}{\pi_{v}+\varphi} & 0
\end{array}\right]
$$

Berdasarkan matriks $\mathbf{N G M}_{2}$, polinom karakteristik yang dihasilkan untuk menentukan nilai $R_{0}$ pada titik kesetimbangan endemik penyakit adalah

$$
P_{2}(x)=\lambda^{4}-1
$$

Sehingga diperoleh nilai $R_{0}$ untuk titik kesetimbangan endemik penyakit sebagai berikut

$$
R_{0}(D E E)=1
$$

\section{SIMULASI DAN INTERPRETASI MODEL MATEMATIKA PENYEBARAN PENYAKIT FILARIASIS DI KABUPATEN SAMBAS}

Simulasi model dalam penelitian ini bertujuan untuk menggambarkan dinamika penyebaran penyakit Filariasis di Kabupaten Sambas dengan menggunakan parameter-parameter dan nilai awal tertentu terkait dengan hasil yang telah dianalisis sebelumnya. Adapun nilai-nilai parameter yang digunakan dalam penelitian ini diberikan pada Tabel 1 berikut 
Tabel 1. Nilai-Nilai Paramater Penyebaran Penyakit Filariasis (per tahun)

\begin{tabular}{|c|c|c|c|}
\hline Parameter & Nilai & Parameter & Nilai \\
\hline$A_{h}$ & 0,01 & $\delta$ & 0,09 \\
\hline$\mu_{h}$ & 0,05 & $A_{v}$ & 1 \\
\hline$\gamma$ & 0,0000034 & $\pi_{v}$ & 0,008 \\
\hline$\theta$ & 0,016 & $\beta$ & 0,00014 \\
\hline$\alpha$ & 0,8 & $\varphi$ & 0,0005 \\
\hline
\end{tabular}

Dengan nilai $N_{h}=526.367$ dan $N_{v}=10.000$ serta nilai awal $S_{h}(0)=292.386, E_{h}(0)=11$, $I_{h}(0)=62, R_{h}(0)=233.908, S_{v}(0)=7.000, E_{v}(0)=2.000$ dan $I_{v}(0)=1.000$. Berdasarkan nilainilai parameter tersebut, diperoleh nilai eigen untuk titik kesetimbangan bebas penyakit yaitu $\lambda_{1}=-0,050 ; \lambda_{2}=-0,850 ; \lambda_{3}=-0,008 ; \lambda_{4}=-0,140 ; \lambda_{5}=-0,016 ; \lambda_{6}=-0,008 ;$ dan $\lambda_{7}=-0,008$. Berdasarkan hasil simulasi numerik diketahui bahwa semua nilai eigen yang didapat dari titik kesetimbangan bebas penyakit berupa bilangan real negatif, akibatnya titik kesetimbangan $T K_{1}$ bersifat stabil asimtotik [4]. Sedangkan nilai eigen untuk titik endemik penyakit yaitu $\lambda_{1}=-0,050 ; \lambda_{2}=-0,140 ; \quad \lambda_{3}=-0,041 ; \lambda_{4}=0,023 ; \lambda_{5}=-0,006+0,030 i ; \lambda_{6}=-0,006-0,030 i ;$ dan $\lambda_{7}=-0,008$. Dari hasil simulasi numerik diketahui bahwa terdapat satu nilai eigen yang didapat dari titik kesetimbangan endemik penyakit berupa bilangan real positif, akibatnya titik kesetimbangan $T K_{2}$ bersifat tidak stabil [4].

Selanjutnya, hasil simulasi numerik model penyebaran penyakit Filariasis untuk 20 tahun mendatang dapat dilihat pada Gambar 2 berikut:

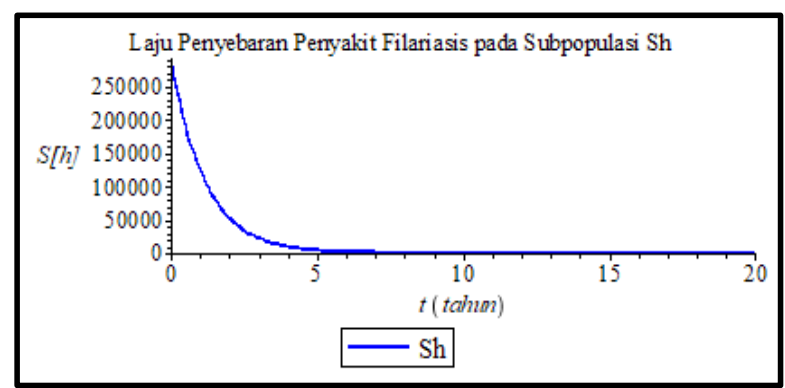

(a)

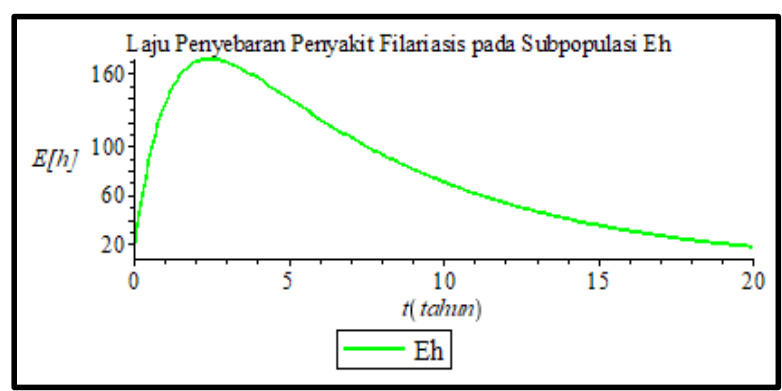

(c)

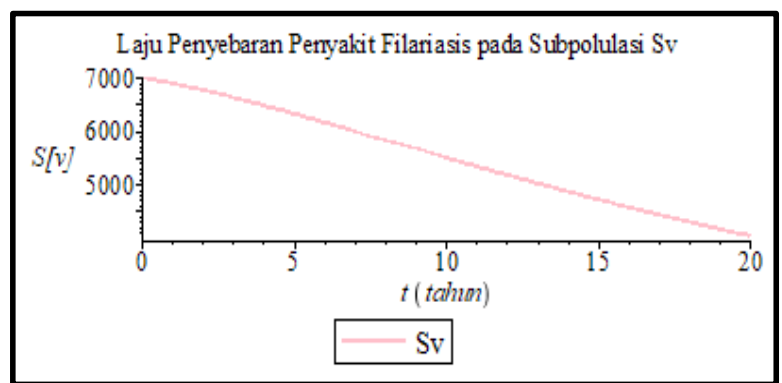

(e)

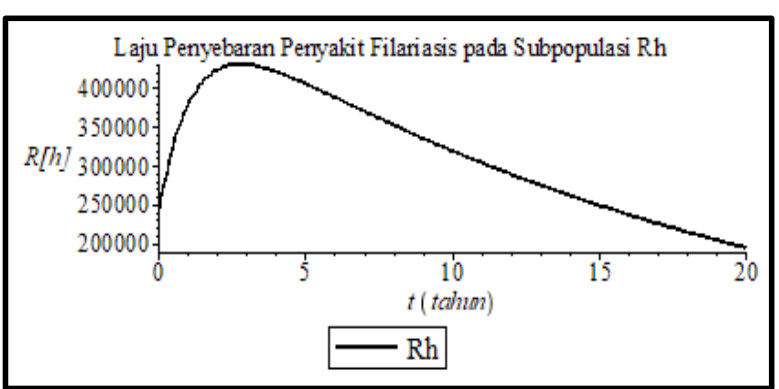

(b)

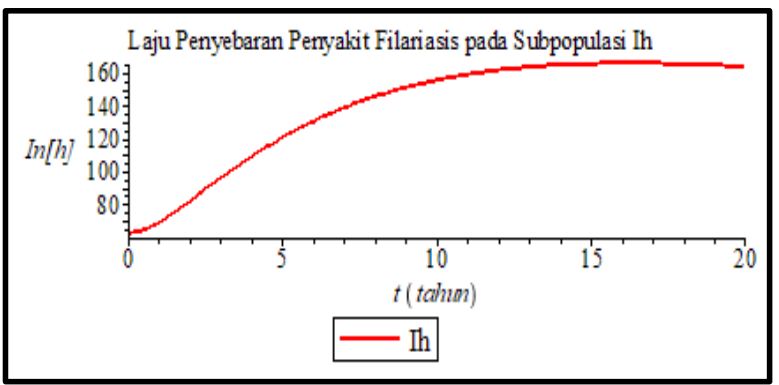

(d)

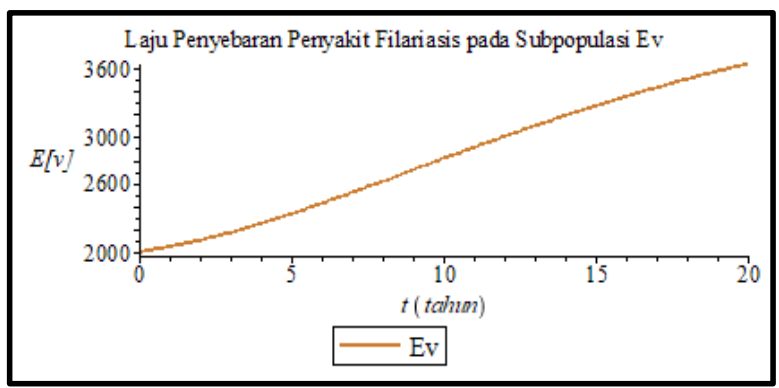

(f) 


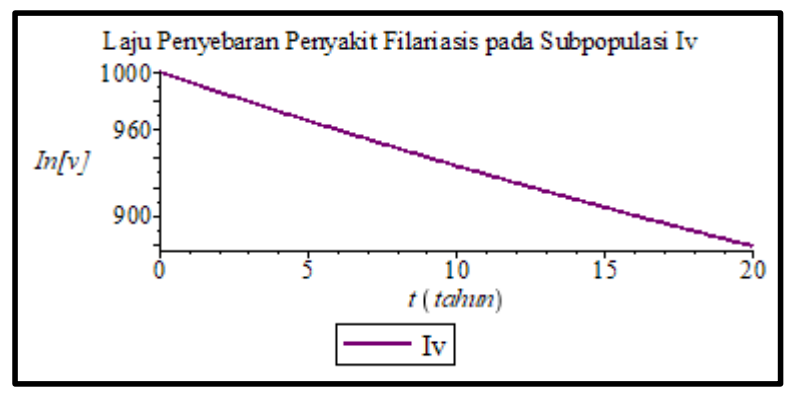

(g)

Gambar 2. Grafik Laju Penyebaran Penyakit Filariasis pada Setiap Populasi

Berdasarkan Gambar 2 (a), jumlah individu pada subpopulasi $S_{h}$ mengalami penurunan dari mulamula 292.836 manusia yang rentan pada waktu $t=0$ tahun menjadi 0 manusia yang rentan kurang lebih pada waktu $t=8$ tahun. Hal ini terjadi karena adanya interaksi antara nyamuk yang terinfeksi dengan manusia yang rentan dan ketidakberhasilan pemberian obat pencegahan Filariasis yang diberikan kepada manusia yang rentan menyebabkan berpindahnya individu pada subpopulasi $S_{h}$ ke $E_{h}$, selain itu dipengaruhi juga oleh keberhasilan pemberian obat pencegahan Filariasis pada manusia yang rentan mengakibatkan berpindahnya individu pada subpopulasi $S_{h}$ ke $R_{h}$, serta adanya kematian alami dari populasi manusia sehingga subpopulasi $S_{h}$ menurun.

Berdasarkan Gambar 2 (b), jumlah individu pada subpopulasi $R_{h}$ mengalami peningkatan dari mulamula ada sekitar 233.908 manusia yang kebal terhadap penyakit pada waktu $t=0$ tahun menjadi sekitar 430.000 manusia yang kebal terhadap penyakit pada waktu kurang lebih $t=3$ tahun. Hal ini terjadi karena keberhasilan dari pemberian obat pencegahan Filariasis pada subpopulasi $S_{h}$ yang cukup besar sehingga individu pada subpopulasi $S_{h}$ mengalami kekebalan terhadap penyakit Filariasis yang menyebabkan individu pada subpopulasi $R_{h}$ juga mengalami peningkatan pada rentang waktu tersebut. Pada $t=4$ tahun dan seterusnya jumlah individu pada subpopulasi $R_{h}$ mengalami penurunan secara terus menerus hingga menuju titik nol pada waktu tertentu. Hal ini disebabkan karena menurunnya jumlah individu pada subpopulasi $S_{h}$ dan juga dipengaruhi oleh adanya kematian alami dari populasi manusia sehingga individu pada subpopulasi $R_{h}$ menurun.

Berdasarkan Gambar 2 (c), jumlah individu pada subpopulasi $E_{h}$ mengalami peningkatan dari mulamula 11 manusia yang terjangkit pada waktu $t=0$ tahun menjadi sekitar 170 manusia yang terjangkit pada waktu kurang lebih $t=3$ tahun. Hal ini dikarenakan adanya interaksi antara nyamuk yang terinfeksi dengan manusia yang rentan dan ketidakberhasilan pemberian obat pencegahan yang diberikan sehingga berpindahnya individu pada subpopulasi $S_{h}$ ke $E_{h}$ menyebabkan individu pada subpopulasi $E_{h}$ mengalami peningkatan. Pada $t=4$ tahun dan seterusnya jumlah individu pada subpopulasi $E_{h}$ mengalami penurunan secara terus menerus dari 170 manusia terjangkit hingga menuju titik nol pada waktu tertentu. Hal ini dikarenakan menurunnya jumlah individu pada subpopulasi $S_{h}$ dan karena berkembangnya penyakit sehingga individu yang terjangkit menjadi terinfeksi menyebabkan berpindahnya individu pada subpopulasi $E_{h}$ ke $I_{h}$, serta adanya kematian alami dari populasi manusia sehingga individu pada subpopulasi $E_{h}$ menurun.

Berdasarkan Gambar 2 (d), jumlah individu pada subpopulasi $I_{h}$ mengalami peningkatan dari mulamula 62 manusia yang terinfeksi pada waktu $t=0$ tahun menjadi sekitar 170 manusia yang terinfeksi pada waktu kurang lebih $t=18$ tahun. Hal ini terjadi karena meningkatnya individu pada subpopulasi $E_{h}$ pada waktu tertentu menyebabkan individu pada subpopulasi $I_{h}$ juga mengalami peningkatan. Pada $t=19$ tahun dan seterusnya jumlah individu pada subpopulasi $I_{h}$ mulai mengalami penurunan. Hal ini dikarenakan menurunnya jumlah individu pada subpopulasi $E_{h}$ pada waktu tertentu dan karena adanya eliminasi terhadap individu yang terinfeksi sehingga individu pada subpopulasi $I_{h}$ menurun. 
Berdasarkan Gambar 2 (e), jumlah individu pada subpopulasi $S_{v}$ mengalami penurunan yang terjadi secara terus menerus dari mula-mula sekitar 7.000 nyamuk yang rentan pada waktu $t=0$ tahun hingga menuju titik nol pada waktu kurang lebih $t=20$ tahun. Hal ini dikarenakan meningkatnya individu pada subpopulasi $I_{h}$ pada waktu tertentu menyebabkan interaksi antara manusia yang terinfeksi dengan nyamuk yang rentan juga meningkat yang berakibat berpindahnya individu pada subpopulasi $S_{v}$ ke $E_{v}$ dan karena adanya kematian alami dari populasi nyamuk sehingga subpopulasi $S_{v}$ menurun.

Berdasarkan Gambar 2 (f), jumlah individu pada subpopulasi $E_{v}$ mengalami peningkatan secara terus menerus dari mula-mula sekitar 2.000 nyamuk yang terjangkit penyakit pada waktu $t=0$ tahun menjadi sekitar 3.600 nyamuk yang terjangkit pada waktu kurang lebih $t=20$ tahun. Hal ini dikarenakan meningkatnya individu pada subpopulasi $I_{h}$ pada waktu tertentu menyebabkan interaksi antara manusia yang terinfeksi dengan nyamuk yang rentan juga meningkat sehingga individu pada subpopulasi $E_{v}$ terus bertambah dari tahun ke tahun.

Berdasarkan Gambar $2(\mathrm{~g})$, jumlah individu pada subpopulasi $I_{v}$ mengalami penurunan secara terus menerus dari mula-mula sekitar 1.000 nyamuk yang terinfeksi pada waktu $t=0$ tahun hingga menuju titik nol kurang lebih pada waktu $t=20$ tahun. Hal ini dikarenakan adanya kematian alami dari populasi nyamuk sehingga subpopulasi $I_{v}$ menurun.

\section{ANALISIS SENSITIVITAS}

Analisis sensitivitas pada penelitian ini dilakukan untuk mengetahui hubungan antara parameter satu terhadap parameter lainnya pada level set $R_{0}$. Adapun analisis yang dilakukan adalah sebagai berikut:

a. Hubungan antara rata-rata kelahiran alami manusia $\left(A_{h}\right)$ terhadap keberhasilan pemberian obat pencegahan Filariasis pada populasi manusia $(\alpha)$ pada level set $R_{0}$.

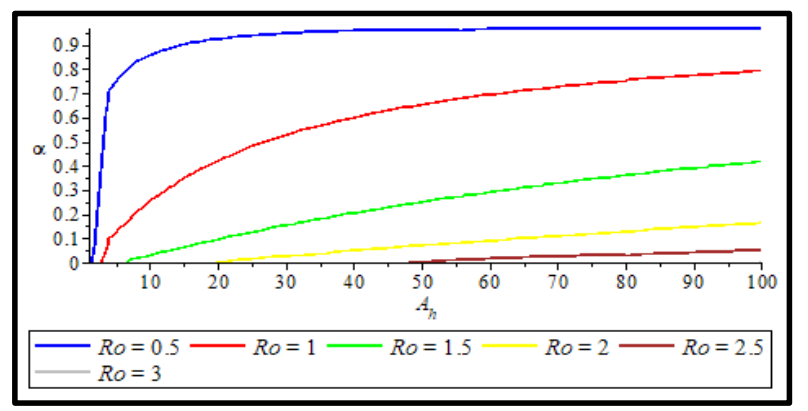

Gambar 3. Grafik Simulasi Hubungan antara $A_{h}$ terhadap $\alpha$ pada Level Set $R_{0}$

Berdasarkan Gambar 3, dapat dilihat bahwa nilai $A_{h}$ dan $\alpha$ mempengaruhi nilai $R_{0}$. Semakin kecil angka kelahiran alami manusia $\left(A_{h}\right)$ dan semakin besar keberhasilan pemberian obat pencegahan Filariasis pada populasi manusia $(\alpha)$, maka nilai $R_{0}$ semakin kecil menyebabkan nilai $R_{0}<1$ yang berarti bahwa penyakit Filariasis di Kabupaten Sambas semakin berkurang bahkan hilang pada suatu waktu tertentu. Sebaliknya, semakin besar angka kelahiran alami manusia $\left(A_{h}\right)$ dan semakin kecil angka keberhasilan pemberian obat pencegahan Filariasis pada populasi manusia $(\alpha)$, maka nilai $R_{0}$ semakin besar menyebabkan nilai $R_{0}>1$ yang berarti bahwa penyakit Filariasis di Kabupaten Sambas menjadi endemik pada suatu waktu tertentu. Hal ini sesuai dengan kondisi pada dunia nyata bahwa semakin kecil nilai kelahiran alami manusia dan semakin besar keberhasilan obat pencegahan Filariasis yang diberikan di dalam suatu populasi mengakibatkan jumlah individu yang rentan terkena penyakit semakin berkurang. Sebaliknya, semakin besar nilai kelahiran alami manusia dan semakin kecil keberhasilan obat pencegahan Filariasis yang diberikan di dalam suatu populasi mengakibatkan jumlah individu yang rentan terkena penyakit semakin meningkat. 
b. Hubungan antara tingkat keberhasilan pemberian obat pencegahan Filariasis pada populasi manusia $(\alpha)$ terhadap laju penyebaran penyakit dari populasi nyamuk ke populasi manusia $(\gamma)$ pada level set $R_{0}$.

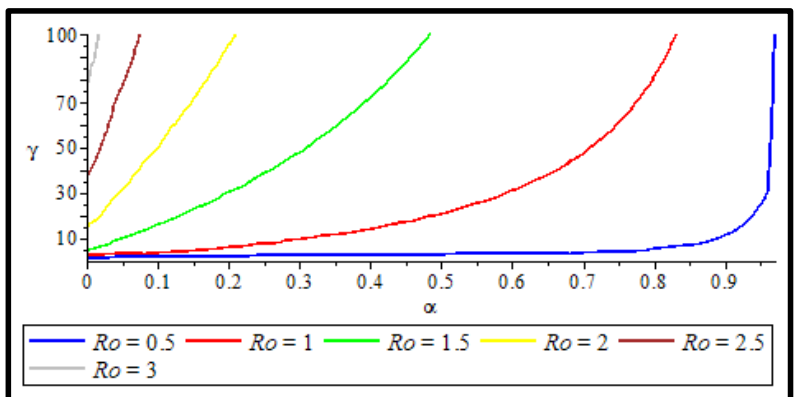

Gambar 4. Grafik Simulasi Hubungan antara $\alpha$ terhadap $\gamma$ pada Level Set $R_{0}$

Berdasarkan Gambar 4, semakin besar keberhasilan pemberian obat pencegahan Filariasis pada populasi manusia $(\alpha)$ dan semakin kecil laju penyebaran penyakit dari populasi nyamuk ke populasi manusia $(\gamma)$, maka nilai $R_{0}$ semakin kecil menyebabkan nilai $R_{0}<1$ yang berarti penyakit Filariasis di Kabupaten Sambas berkurang bahkan hilang pada suatu waktu tertentu. Sebaliknya, semakin kecil keberhasilan pemberian obat pencegahan Filariasis pada populasi manusia $(\alpha)$ dan semakin besar laju penyebaran penyakit dari populasi nyamuk ke populasi manusia $(\gamma)$, maka nilai $R_{0}$ semakin besar menyebabkan nilai $R_{0}>1$ yang berarti penyakit Filariasis di Kabupaten Sambas menjadi endemik pada suatu waktu tertentu. Hal ini sesuai dengan kondisi nyata bahwa semakin kecil laju penyebaran penyakit dan semakin besar keberhasilan pemberian obat pencegahan Filariasis di dalam suatu populasi menyebabkan jumlah individu yang terinfeksi penyakit semakin berkurang. Sebaliknya, semakin besar laju penyebaran penyakit dan semakin kecil keberhasilan pemberian obat pencegahan Filariasis di dalam suatu populasi menyebabkan jumlah individu yang terinfeksi penyakit bertambah.

\section{PENUTUP}

Beberapa kesimpulan dalam penelitian ini antara lain:

1. Model matematika untuk penyebaran penyakit Filariasis adalah sebagai berikut:

$$
\begin{aligned}
\frac{d S_{h}}{d t} & =A_{h}-(1-\alpha) \gamma S_{h} I_{v}-\left(\mu_{h}+\alpha\right) S_{h} \\
\frac{d E_{h}}{d t} & =(1-\alpha) \gamma S_{h} I_{v}-\left(\mu_{h}+\delta\right) E_{h} \\
\frac{d I_{h}}{d t} & =\delta E_{h}-\theta I_{h} \\
\frac{d R_{h}}{d t} & =\alpha S_{h}-\mu_{h} R_{h} \\
\frac{d S_{v}}{d t} & =A_{v}-\beta I_{h} S_{v}-\pi_{v} S_{v} \\
\frac{d E_{v}}{d t} & =\beta S_{v} I_{h}-\left(\pi_{v}+\varphi\right) E_{v} \\
\frac{d I_{v}}{d t} & =\varphi E_{v}-\pi_{v} I_{v}
\end{aligned}
$$

2. Analisis model matematika penyebaran penyakit Filariasis menghasilkan dua titik kesetimbangan, yaitu

a. Titik kesetimbangan bebas penyakit

$$
T K_{1}=\left(S_{h 1}, E_{h 1}, I_{h 1}, R_{h 1}, S_{v 1}, E_{v 1}, I_{v 1}\right)=\left(\frac{A_{h}}{\mu_{h}+\alpha}, 0,0, \frac{\alpha A_{h}}{\left(\mu_{h}+\alpha\right) \mu_{h}}, \frac{A_{v}}{\pi_{v}}, 0,0\right)
$$

b. Titik kesetimbangan endemik penyakit

$$
\begin{aligned}
T K_{2} & =\left(S_{h 2}, E_{h 2}, I_{h 2}, R_{h 2}, S_{v 2}, E_{v 2}, I_{v 2}\right) \\
& =\left(\frac{\left(\theta\left(\mu_{h}+\delta\right) \pi_{v}+A_{h} \beta \delta\right) \pi_{v}\left(\varphi+\pi_{v}\right)}{\beta \delta\left(\left(\mu_{h}+\alpha\right) \pi_{v}{ }^{2}+\varphi\left(\mu_{h}+\alpha\right) \pi_{v}-\varphi A_{v} \gamma(\alpha-1)\right)^{\prime}}\right.
\end{aligned}
$$




$$
\begin{aligned}
& \frac{-\theta\left(\mu_{h}+\delta\right)\left(\mu_{h}+\alpha\right) \pi_{v}{ }^{3}-\varphi \theta\left(\mu_{h}+\delta\right)\left(\mu_{h}+\alpha\right) \pi_{v}{ }^{2}-A_{h} \varphi A_{v} \beta \delta \gamma(\alpha-1)}{\beta \delta\left(\mu_{h}+\delta\right)\left(\left(\mu_{h}+\alpha\right) \pi_{v}{ }^{2}+\varphi\left(\mu_{h}+\alpha\right) \pi_{v}-\varphi A_{v} \gamma(\alpha-1)\right)}, \\
& \frac{-\theta\left(\mu_{h}+\delta\right)\left(\mu_{h}+\alpha\right) \pi_{v}{ }^{3}-\varphi \theta\left(\mu_{h}+\delta\right)\left(\mu_{h}+\alpha\right) \pi_{v}{ }^{2}-A_{h} \varphi A_{v} \beta \delta \gamma(\alpha-1)}{\beta \theta\left(\mu_{h}+\delta\right)\left(\left(\mu_{h}+\alpha\right) \pi_{v}{ }^{2}+\varphi\left(\mu_{h}+\alpha\right) \pi_{v}-\varphi A_{v} \gamma(\alpha-1)\right)}, \\
& \frac{\alpha \pi_{v}\left(\theta\left(\mu_{h}+\delta\right) \pi_{v}+A_{h} \beta \delta\right)\left(\varphi+\pi_{v}\right)}{\beta \delta\left(\left(\mu_{h}+\alpha\right) \pi_{v}{ }^{2}+\varphi\left(\mu_{h}+\alpha\right) \pi_{v}-\varphi A_{v} \gamma(\alpha-1)\right) \mu_{h}{ }^{\prime}} \\
& -\frac{\theta\left(\mu_{h}+\delta\right)\left(\left(\mu_{h}+\alpha\right) \pi_{v}{ }^{2}+\varphi\left(\mu_{h}+\alpha\right) \pi_{v}-\varphi A_{v} \gamma(\alpha-1)\right)}{(\alpha-1)\left(\theta\left(\mu_{h}+\delta\right) \pi_{v}+A_{h} \beta \delta\right) \varphi \gamma}, \\
& \frac{\theta\left(\mu_{h}+\delta\right)\left(\mu_{h}+\alpha\right) \pi_{v}{ }^{3}+\varphi \theta\left(\mu_{h}+\delta\right)\left(\mu_{h}+\alpha\right) \pi_{v}{ }^{2}+A_{h} \varphi A_{v} \beta \delta \gamma(\alpha-1)}{(\alpha-1)\left(\theta\left(\mu_{h}+\delta\right) \pi_{v}+A_{h} \beta \delta\right) \varphi \gamma\left(\varphi+\pi_{v}\right)}, \\
& \left.\frac{\theta\left(\mu_{h}+\delta\right)\left(\mu_{h}+\alpha\right) \pi_{v}{ }^{3}+\varphi \theta\left(\mu_{h}+\delta\right)\left(\mu_{h}+\alpha\right) \pi_{v}{ }^{2}+A_{h} \varphi A_{v} \beta \delta \gamma(\alpha-1)}{(\alpha-1)\left(\theta\left(\mu_{h}+\delta\right) \pi_{v}+A_{h} \beta \delta\right) \pi_{v} \gamma\left(\varphi+\pi_{v}\right)}\right) .
\end{aligned}
$$

Berdasarkan hasil simulasi numerik analisis kestabilan pada titik kesetimbangan diperoleh kestabilan sistem pada model matematika penyebaran penyakit Filariasis adalah stabil asimtotik untuk titik kesetimbangan bebas dan tidak stabil untuk titik kesetimbangan endemik penyakit.

3. Berdasarkan hasil analisis sensitivitas dari simulasi numerik pada penderita Filariasis di Kabupaten Sambas dengan nilai awal dan parameter yang telah diberikan, diperoleh bahwa:

a. Semakin kecil angka kelahiran alami manusia $\left(A_{h}\right)$ dan semakin besar keberhasilan pemberian obat pencegahan Filariasis pada populasi manusia $(\alpha)$, maka nilai $R_{0}$ semakin kecil menyebabkan nilai $R_{0}<1$ yang berarti penyakit Filariasis di Kabupaten Sambas semakin berkurang bahkan hilang pada suatu waktu tertentu, begitu juga sebaliknya.

b. Semakin besar keberhasilan pemberian obat pencegahan Filariasis pada populasi manusia $(\alpha)$ dan semakin kecil laju penyebaran penyakit dari populasi nyamuk ke populasi manusia $(\gamma)$, maka nilai $R_{0}$ semakin kecil sehingga menyebabkan nilai $R_{0}<1$ yang berarti penyakit Filariasis di Kabupaten Sambas berkurang bahkan hilang pada suatu waktu tertentu, begitu juga sebaliknya.

\section{DAFTAR PUSTAKA}

[1] Kementerian Kesehatan RI. Situasi Filariasis di Indonesia Tahun 2015. Jakarta: Pusdatin; 2016.

[2] Perko L. Differential Equations and Dynamical Systems Third Edition. United States of America: Springer-Verlag; 2001.

[3] Driessche P, Watmough J. Reproduction Number and Sub-Threshold Endemic Equilibria for Compartemental Models of Disease Transmission. Mathematical Biosciences. 2002; 180: 29-48.

[4] Boyce WE, DiPrima RC. Elementary Differential Equations and Boundary Value Problems Ninth Edition. United States of America: John Wiley and Sons, Inc; 2009.

[5] Anton H, Rorres C. Aljabar Linear Elementer Versi Aplikasi Ed ke-8. Jakarta: Erlangga; 2004.

NURHAJIJAH

HELMI

WORO BUDIARTINI PARTIWI
: Jurusan Matematika FMIPA Untan, Pontianak, nnurhajijah@gmail.com

: Jurusan Matematika FMIPA Untan, Pontianak, helmi132205@yahoo.co.id

: Jurusan Matematika FMIPA Untan, Pontianak, woro.partiwi@gmail.com 